\title{
Universities and start-up creation by Ph.D. graduates: the role of scientific and social capital of academic laboratories
}

\author{
Alessandro Muscio $^{1} \cdot$ Sotaro Shibayama ${ }^{2}$ (D) Laura Ramaciotti $^{3}$
}

Accepted: 29 December 2020 / Published online: 4 February 2021

(c) The Author(s) 2021

\begin{abstract}
This paper investigates how the characteristics of university laboratories influence the propensity of Ph.D. students to entrepreneurship, and thus, contribute to the transfer of academic knowledge to society. As determinants of Ph.D. entrepreneurship, we focus on the lab scientific and social capital as well as on the business experience that Ph.D. students acquire during their training period. The empirical exercise is based on questionnaire survey data of $5266 \mathrm{Ph} . \mathrm{D}$. students in Italian universities in all subject areas. First, we find that $6.7 \%$ of the $\mathrm{Ph} . \mathrm{D}$. graduates engage in startup activities, and thus, Ph.D. training seems to contribute to knowledge transfer through entrepreneurship. Second, Ph.D. entrepreneurship is driven by business experience, in the forms of industry collaboration and industrially applicable research projects, during their training period. Third, the lab scientific capital is negatively associated with Ph.D. entrepreneurship, suggesting a conflict between scientific excellence and entrepreneurship, but this effect is mitigated if students acquire business experience. Fourth, the lab social capital increases the chance of startup when students have business experience. We further investigate the effects of lab environment by distinguishing between startups that are based on university research and startups that are not, finding different determinants.
\end{abstract}

Keywords Student entrepreneurship $\cdot$ Entrepreneurial university $\cdot$ Start-up $\cdot$ Ph.D. · Firm creation - Academic training

Sotaro Shibayama

sotaro.shibayama@fek.lu.se

1 Dipartimento di Economia, Management e Territorio (DEMeT), Università di Foggia, Foggia, Italy

2 Department of Business Administration, School of Economics and Management, Lund University, P.O. Box 7080, 22007 Lund, Sweden

3 Dipartimento di Economia e Management, Università di Ferrara, Ferrara, Italy 


\section{Introduction}

Political pressure is currently being put on universities to stimulate and support entrepreneurship. The growing concern in public opinion about the integration between academic institutions and industry and their general impact on society has led to the definitive affirmation of the 'entrepreneurial university' model (Clark 1998; Etzkowitz et al. 2000), evidencing the key role of universities in promoting the establishment of business ventures.

Among all the routes of academic engagement with industry (see Muscio and Vallanti 2014), starting up a company based on scientific research results is an important one, particularly when technology transfer requires a high level of commitment on the side of academics. The literature on this topic has been dynamic; while empirical works on 'tangible' forms of knowledge transfer, ranging from patenting to licensing activity are abundant, investigations on academic entrepreneurship via academic spin-offs has become more prominent over the last decade, as an increasing number of academics have chosen and been encouraged to engage in entrepreneurial activities. Notwithstanding the role of spinoffs in sustaining academic entrepreneurship, prior literature has thus far focused almost exclusively on licensing and startups by faculty and staff, largely ignoring entrepreneurship by students (Astebro et al. 2012; Hayter et al. 2017; Shah and Pahnke 2014). In addition, the literature has studied university spinoff mainly as a secondary activity of academic staff (e.g. professors). However, we observe increasing incidents of startups by students-particularly by $\mathrm{Ph} . \mathrm{D}$. students - as academic institutions are encouraging them to become more entrepreneurial by offering entrepreneurship courses, supporting facilities such as business incubators, business competitions, and innovation prizes.

Startup by Ph.D. students (Ph.D. entrepreneurship, hereafter) is peculiar in that it is situated at the intersection of the three academic missions: teaching, research and academic engagement. That is, Ph.D. entrepreneurs transfer the result of academic research, developed through graduate education, to the society. Thus, it is of interest for the purpose of science and technology (S\&T) policies to better understand what factors support Ph.D. entrepreneurship and under what circumstances students choose to establish new ventures. Nonetheless, prior research is scarce.

$\mathrm{Ph} . \mathrm{D}$. entrepreneurship is of theoretical interest also because it is considered as a career choice, unlike startup by academic staff in which entrepreneurship is an additional engagement. That is, students make a choice between academic careers and self-employment careers (though it is possible that students start up a business while being postdocs, etc.). It is plausible that students choose to startup because of dissatisfaction with academic careers. If such is the case, the effectiveness of Ph.D. entrepreneurship could be dubious. In this regard, understanding conditions for Ph.D. entrepreneurship is also of practical interest.

This study thus aims to understand what conditions lead Ph.D. students to start up new businesses, thereby to transfer academic knowledge to the society. We argue that Ph.D. entrepreneurship needs business experience, scientific expertise, and social network, and as a device to provide these opportunities and resources, we focus on the local environment of university laboratories where Ph.D. students receive academic training. We examine the impact of these factors on Ph.D. students' postgraduate startup activities, drawing on the data of a questionnaire administered by CINECA in 2016 and responded by 5266 Ph.D. graduates from Italian academic institutions.

The paper is organised as follows. Section 2 presents the theoretical background and the research hypotheses; Sect. 3 describes the data and methodology used in the empirical 
analysis; Sect. 4 presents the results of an econometric analysis; and Sect. 5 presents some theoretical and policy implications and concluding remarks.

\section{Theoretical background}

Academic entrepreneurship is a complex phenomenon that involves several stakeholders, ranging from faculty staff to post-doctoral fellows and students, who choose to become entrepreneurs. Among others, entrepreneurial activities by Ph.D. students, though largely neglected in prior literature, deserve special attention for several reasons. First, Ph.D. students may be better placed than academic staff to overcome the obstacles to the creation of new ventures. Unlike academic staff, as stressed by Colombo and Piva (2012), students do not need a 'genetic mutation' to become entrepreneurs and are often well positioned in gaining access to business competences. Second, entrepreneurship can be a viable job option for Ph.D. graduates, who seek to exploit the knowledge and skills learned through the training. Third, unlike undergraduate students, Ph.D. students have direct access to knowledge-intensive business ideas, which they develop through their training period and can exploit for startup.

Prior literature on academic entrepreneurship roughly falls into two groups; one group concerns institutional environment, while the other investigates the individual traits of entrepreneurs (Castillo Holley and Watson 2017). Although entrepreneurship can be considered as an individual activity (Shane and Venkataraman 2000), recent evidence has highlighted that academic institutions can influence Ph.D. entrepreneurs in many ways (Dooley and Kenny 2015). For example, Muscio and Ramaciotti (2019) focus on the characteristics of Ph.D. courses and the entrepreneurial climate of a university. In this study, we particularly investigate the role of university laboratories where Ph.D. students receive research training from their supervisors.

Entrepreneurial activities normally take place in an organisational context (Autio et al. 2014; Walter et al. 2013), oftentimes through the interaction with peer researchers (Bergmann et al. 2016). In this respect, a university lab offers an organisational basis for scientific research, research training, and career building. Labs consist of a lab head and member researchers, including students, under the lab head's supervision. As noted by Olmos-Peñuela et al. (2014), a lab head can influence the behaviour of lab members in establishing research priorities, steering the research activities of the lab, and mobilising the organisation of tasks and commitment. Compared to cross-organisational collaboration, labs are meant to serve for longer-term and broader goals, such as project portfolio management and accumulation and reuse of local knowledge (Blau 1994; Latour and Woolgar 1979; Knorr-Cetina 1999). Research training for students is one of the long-term goals of university labs (Shibayama et al. 2015). Literature has suggested that lab training and interpersonal relationship with supervisors determine the future prospect of students (Long et al. 1979; Miller et al. 2005; Shibayama 2019).

In academic entrepreneurship by students, they rely on the lab and on their supervisors for at least three important resources: (1) the scientific capital and resources, which students can directly or indirectly transfer to their business; (2) the social capital of the research team, which opens up access to external national or international network, exposing their ideas to a broader audience; and (3) the entrepreneurial and business experience, which allows students to obtain business contacts and test the validity of their idea for practical purposes. 
These factors are also relevant in students' career choices. While non-student academic entrepreneurship tends to be a side activity, student startup can mean departure from academia. In fact, only a small number of Ph.D. graduates eventually obtain secure academic employment (Puljak and Sharif 2009), and the rest move to non-academic careers (Hayter and Parker 2019). Though the majority of Ph.D. candidates aim to find an academic job, at least when they decide to join Ph.D. programme (Conti and Visentin 2015; Mangematin 2000), other career options, including academic entrepreneurship, are of increasing relevance as academic careers have become destabilised (Fitzenberger and Schulze 2014; Sauermann and Roach 2016). The following sections discuss the theoretical underpinnings of these factors.

\subsection{Business experience}

The first factor influencing Ph.D. students' choice to become entrepreneurs is the business experience they obtain through working in the lab. How students are exposed to entrepreneurship during their training period is critical (Hayter et al. 2017). While entrepreneurship programmes can nurture and stimulate startup activities (Maresch et al. 2016; Muscio and Ramaciotti 2019), the literature emphasises that access to relevant business networks and learning-by-doing through research projects are far more effective than simply attending dedicated courses (Rasmussen and Sorheim 2006).

Business experience can stem from various sources, such as collaboration with industry, contract research, consultancy work, and engagement in industry-oriented research projects. For example, the literature finds that industry contract research is associated with academic entrepreneurship (Muscio et al. 2016; Powers and McDougall 2005; Van Looy et al. 2011). University-industry interaction stimulates the establishment of business contacts and the accumulation of capabilities for new venture creation (D'Este et al. 2012; Wright et al. 2004). Individual-level studies show that academics who engage in collaboration agreements with industry tend to be involved in commercially oriented activities (Blumenthal et al. 1996) and become entrepreneurs (Landry et al. 2006; Krabel and Mueller 2009). While academics inclined towards entrepreneurship can be self-selected to engage in business experience (Fini et al. 2010; Philpott et al. 2011), business experience can work as an incubation device for starting up businesses.

These factors can play a substantial role in students' entrepreneurship. As students in general have little experience in engaging with the private sector, any opportunity to interact with company representatives and exposure to real-world problems can encourage them to pursue applications to an industrial context and eventually to become entrepreneurs. From an educational perspective, interaction with businesses provides additional resources (Muscio et al. 2013) and complementary learning opportunities that academic institutions cannot provide alone (Lester and Costley 2010; Kessels and Kwakman 2007; Slaughter et al. 2002; Thune and Støren 2015). For example, labs with intensive ties with industry can provide a favourable environment for entrepreneurship (Walter et al. 2013). Through direct interaction with company representatives, students can learn their practical skills, expands their networks, and exposes them to real-world business problems (Brindley and Ritchie 2000; Ridder and Van der Sijde 2003). Supervisors engaged in industry relations are also likely to have better understanding of contemporary industry challenges and perhaps the experience of startup itself (Krabel and Mueller 2009), which can be shared with students. 
In summary, we argue that business experience in labs should increase students' exposure to commercial needs and encourage them to apply their knowledge and technologies for practical purposes. Therefore, we hypothesise as follows:

Hypothesis 1: The business experience in the lab is positively associated with Ph.D. students' startup activity.

\subsection{The scientific capital}

The second university-level factor that can influence Ph.D. students' choice is the scientific capital of the lab embodied in several factors. For example, it depends on the academic skills of the research supervisor, who guides students' research projects, pointing them towards interesting new areas of research and towards suitable methodologies (Laudel 2001; Shibayama et al. 2015). The excellence of research environment is also influenced by the availability of physical and financial resources, which determine how certain research tasks can be performed, the capacity to purchase equipment and material, and opportunities of conference participation and publication. Other factors embedded in scientific capital are the time devoted to research by students and their autonomy in research activities. In some contexts, Ph.D. students can be occupied with teaching and other activities, which can hinder scientific performance.

The extant literature finds a positive association between the scientific capital and academic engagement. For example, Muscio et al. (2013) find that higher research quality increases the amount of contract research that labs obtain from the business sector. Similarly, there is evidence that universities where high-quality research is performed tend to attract private funding, further reinforcing the process of investing in excellent research (European Commission 2010; McCormack et al. 2014). 'Star scientists' who publish more papers with higher impact are more likely to commercialise successfully their research results (Lowe and Gonzalez-Brambila 2007; Zucker and Darby 1996; Zucker et al. 1998). Several authors examined whether trade-offs exist between research performance and the engagement in commercialisation activity (Azoulay et al. 2009; Fabrizio and DiMinin 2008; Lowe and Gonzalez-Brambila 2007; Stephan et al. 2007), indicating that there is a positive relationship between academic and commercial success. There is also evidence that research labs led by star scientists tend to be more engaged in knowledge transfer activities (D’Este and Perkmann 2011; Landry et al. 2010; Olmos-Peñuela et al. 2014). Reputational effects can also come into play, as skilled and qualified knowledge deriving from high-quality research has potential signalling effects on investors (Spence 1973). In fact, commercial investors in academic ideas (e.g. venture capitalists) prefer to support firms that have not only a promising business profile but also more skilled human capital (Ramaciotti et al. 2017).

Evidence about the impact of scientific capital specifically on entrepreneurial activity is less conclusive. Some studies suggest that greater research performance is associated with higher degrees of entrepreneurship. Azoulay et al. (2007) and Rasmussen and Borch (2010) suggest that high-quality research helps develop new ideas and innovations that can be commercialised or brought to market by startup ventures. Schiller and Diez (2010), find that star scientists engaged in entrepreneurial activity inspire the members of their research teams, influencing also Ph.D. students to take industry employment. Van Looy et al. (2004) find no trade-off between entrepreneurial and scientific activities in contract researchers. 
From the perspective of regional development, Kirchhoff et al. (2007) demonstrate that university R\&D expenditure is associated with higher levels of regional business creation. Walter et al. (2013) also suggest that top research universities offer a favourable environment for the interaction with businesses and startups because of potential network effects. These results seem to suggest that the scientific capital in the training environment should help students commercialise their research ideas.

However, there can be a trade-off between entrepreneurial activities and traditional scientific research, as entrepreneurial activities can require substantial investment in resources and skillsets that are not necessarily synergistic with traditional scientific research. Accordingly, Olmos-Peñuela et al. (2014) find that research labs led by star scientists are more likely to engage in contract research and consultancy, but that they are not better at academic entrepreneurship. Other scholars fail to find synergies between research performance and spinoff creation (Baldini 2010; Muscio et al. 2016; Ramaciotti and Rizzo 2015). Supporting these results, Walter et al. (2013) find that students' self-employment intentions are generally lower in research-intensive departments.

Particularly in the case of Ph.D. startup, one should consider the fact that entrepreneurship is a career choice. Laboratories with high scientific capital are more likely to offer positions to their graduates at the end of their study period (Long et al. 1979; Miller et al. 2005). In other words, students affiliated to the best laboratories have greater chance to stay in academic employment. This suggests a negative effect of scientific capital on Ph.D. entrepreneurship compared to entrepreneurship by academic staff.

In summary, lab scientific capital has both positive and negative impact on startup activities in general, but the negative side can be stronger in the case of Ph.D. entrepreneurship. We nevertheless argue that argue that scientific capital can be an important driver 'if' complemented with business experience. As most students have no prior business experience, if no such experience is provided during the training period, they would not even think of turning their research ideas into a business. It is far more straightforward to exploit rich scientific capital for conventional scientific activities in the next academic career stage. Business experience can however redirect the use of scientific capital for practical purposes. As discussed, business experience opens up students' perspectives beyond the scientific realm, with which students might find a way to apply the scientific capital for businesses. Therefore, we hypothesise that the co-existence of business experience and high scientific capital should lead to Ph.D. entrepreneurship.

Hypothesis 2: The business experience of the lab positively moderates the impact of the lab scientific capital on Ph.D. students' startup activity.

\subsection{The social capital}

The third university-level factor that can influence Ph.D. students' choice to become entrepreneurs is the lab social capital. Social capital is here intended as the outward orientation of a lab, accounting for its engagement in collaboration with external research teams and in external experiences. Students can reap the benefits that derive from social capital via the participation in collaborative research projects, visits to different research contexts, international conferences, exposure to real-world business problems, and so forth.

The social capital of a lab can facilitate Ph.D. entrepreneurship for a few reasons. First, academic institutions with broader networks tend to be situated closer to the boundaries of scientific discoveries (Knight 2015), which gives students greater access to wide audience. 
This allows students to better respond to societal and business challenges (Knight 2004), encouraging them to pursue commercially relevant research activities and to establish knowledge-based startups. Second, social capital is known as one of the preconditions for entrepreneurship (Ardichvili and Cardozo 2000). Network-based evidence shows that social ties increase the chance of opportunity recognition, which is critical for entrepreneurship (Arenius and De Clercq 2005). Third, students with broader network can grow more open-minded and develop broader research and occupational perspectives (Altbach and Knight 2007), fostering their progression along the entrepreneurial ladder (Felicio et al. 2015; Horta 2010; Minola et al. 2016). Fourth, social capital contributes to the quality of scientific research, which can be then translated into a greater chance of Ph.D. entrepreneurship through the aforementioned positive effects of scientific capital. Therefore, the social capital can facilitate students' business experiences and their startup activities.

Social capital can also affect students' non-entrepreneurial career choices. Social ties and personal networks in the scientific community has been suggested to support academic career progression (Prodan and Drnovsek 2010). For example, research visits during the $\mathrm{Ph} . \mathrm{D}$. period can lead to postdoc hiring at the same host institution, while international conferences are among the few places where students can advertise themselves for future employment to a broader range of scientific peers. Social capital can also help non-academic employment. For example, internationalised institutions provide students with international contacts, easing their potential access to broader job market (Edler et al. 2011; Knight 2004).

In summary, the direct effect of lab social capital on students' startup activities also can be both positive and negative. Nonetheless, we argue that the social capital of a lab can drive Ph.D. entrepreneurship, especially if complemented by rich business experience. As above discussed, the use of social capital is versatile, but it is the students who decide how to exploit the potential opportunities. In this regard, entrepreneurial mindset nurtured by business experience can lead students to focus on specific network ties relevant to entrepreneurial goals. In contrast, if business experience is totally lacking, students are more likely to navigate themselves to a conventional direction and use social capital for an academic career progression. Therefore, we hypothesise as follows:

Hypothesis 3: The business experience of the lab positively moderates the impact of the lab social capital on Ph.D. students' startup activity.

\section{Data and method}

\subsection{Data description}

This work exploits an original set of data obtained from the responses to a questionnaire survey of around 23,500 doctorate students and graduates who were awarded the degree of Ph.D. in Italian academic institutions in all subject areas in the period 2008-2014. ${ }^{1}$ The survey was administered in 2014-2015 by CINECA, a not-for-profit Consortium, made up

\footnotetext{
${ }^{1}$ We invite scholars to further extend the study of university-level factors influencing academic performance in terms of Ph.D. startup activity accessing, free of charge, our database online (see Muscio and Ramaciotti 2018).
} 


\section{(b) Natural Sci \& Engineering}
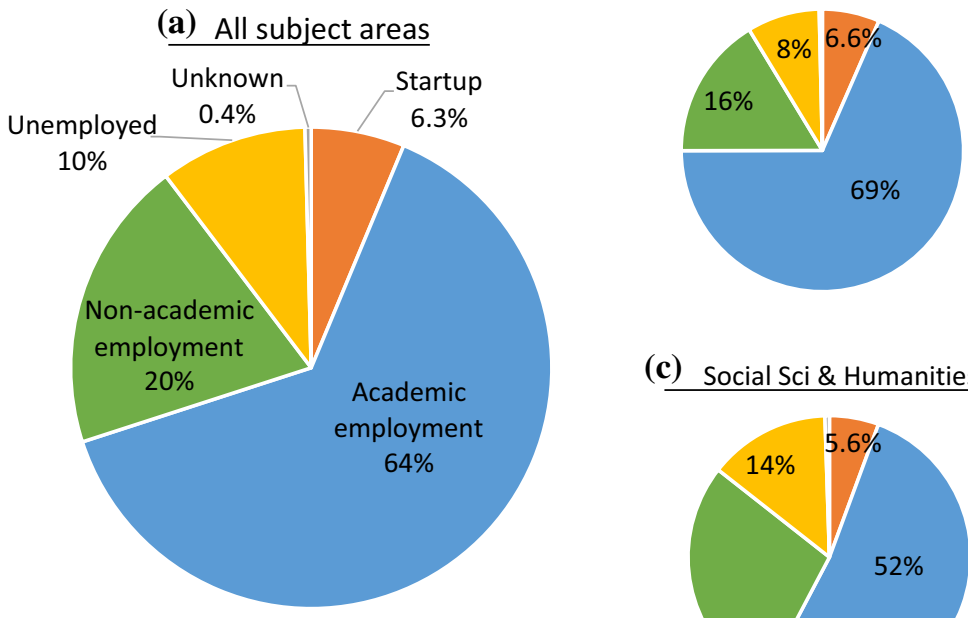

(c) Social Sci \& Humanities

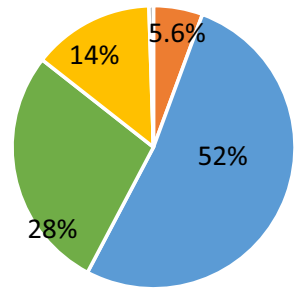

Fig. 1 Career choice of Ph.D. graduates. Note $\mathbf{a} N=5266, \mathbf{b} N=3754$, c $N=1512$

of 67 Italian universities, nine Italian Research Institutions, one Polyclinic and the Italian Ministry of Education and Research (MIUR). 9,062 completed questionnaires were returned. The questionnaire was designed to evaluate the Ph.D. programme and asked students general questions about their training period, their level of satisfaction with the Ph.D. programme, their occupational status and entrepreneurial activities.

The data show that at the time of the survey $68 \%$ of 9,062 respondents completed their Ph.D. studies and $72 \%$ were employed. $6.5 \%$ of respondents had started a business, $87 \%$ of which were still active at the time of the survey.

The sample was reduced to 5266 observations, excluding the responses of those students that had not yet graduated at the time of the survey and those that did not answer relevant questions. Figure 1 presents the career outcomes of graduates. Overall, a relatively high proportion (6.3\%) of the graduates had startup experience. For the rest, $64 \%$ of the graduates are employed in academia, 20\% employed outside of academia, and 10\% unemployed.

Among those who had startup experience, $56 \%$ of the businesses are associated with university technologies and know-how (e.g., university spin-off), whereas $44 \%$ are not related (e.g., corporate spin-off). Furthermore, among the students who engaged in university-related startups, $73 \%$ maintain employment at the university (e.g., postdoc), whereas $27 \%$ did not. This suggests that Ph.D. entrepreneurs often secure an income source on top of their startup businesses. We also break down subject areas into natural sciences and engineering (Fig. 1b) and social sciences and humanities (Fig. 1c). ${ }^{2}$ As noted in Sauermann and Roach (2016), employment outcomes of Ph.D. graduates vary by scientific fields.

\footnotetext{
2 The former includes mathematics, computer sciences, physics, chemistry, geology, biology, medicine, agriculture, and engineering; and the latter includes humanities, philosophy, psychology, law, economics, and political sciences.
} 


\subsection{Measures}

\subsubsection{Ph.D. student's startup and career options}

In order to investigate our research hypotheses, we created two variables concerning $\mathrm{Ph} . \mathrm{D}$. student's engagement in startup activities and other career choices. The first is a dichotomous variable coded 1 if a student started or was involved in the establishment of a startup and 0 otherwise (startup). The second variable distinguishes all career options: (1) startup, (2) academic employment, (3) non-academic employment, and (4) being unemployed. We further break down the types of startup: (1a) university-related startups with academic employment, (1b) university-related startups without academic employment, and (1c) university-unrelated startups, because we expect that they should be explained by different conditions. Taken all together, we prepared a categorical variable with six career options (career option).

\subsubsection{Lab environment}

We prepared two variables for business experience. First, we surveyed the students' experience of collaboration with businesses during the Ph.D. programme and coded a dummy variable 1 if they had any experience and 0 otherwise (industry collaboration). Second, we also surveyed the percentage of research activities during the Ph.D. programme dedicated immediately to industrial application, as opposed to basic research (industry application).

As to lab scientific and social capitals, we prepared a set of survey instrument concerning the local research environment: (a) skills of the research supervisor, (b) time devoted to research activity, (c) tools and research infrastructure, (d) financial resources, (e) autonomy and independence, (f) international research network, and ( $\mathrm{g}$ ) international experience. Each item is measured in six-point scale from 1: very poor to 6: very good. We took the mean value of (a)-(e) as scientific capital, and the mean of (f) and (g) as social capital. The Cronbach's alpha is 0.728 and 0.828 respectively. We also validated the distinction of these two dimensions of lab capitals by a confirmatory factor analysis (Appendix 1).

\subsubsection{Control variables}

We include control variables based on the literature on the determinants of student startup and academic spin-off creation (e.g. Åstebro et al. 2012; Krabel and Muller 2009). This body of work identifies both individual and context level determinants, where the context refers mostly to the characteristic of the university as a whole. At the individual level, several studies emphasise the importance of demographic factors such as age and gender (Abreu and Grinevich 2013; Landry et al. 2006). We control for students' age (year of birth), gender (male), nationality (foreigner), research performance ( $p u b)$, and entrepreneurial background of the parents (parent startup). University-level control variables include the university spinoff performance (university spinoff activity), research performance (university rating), and university size (university size). Finally, since the regional context is relevant for startup creation (Muscio et al. 2016), we introduce a variable for the unemployment rate where the university is located (unemployment rate).

Table 1 presents the variables used in the econometric analyses, and Table 2 shows the descriptive statistics and correlation matrix of the variables. 


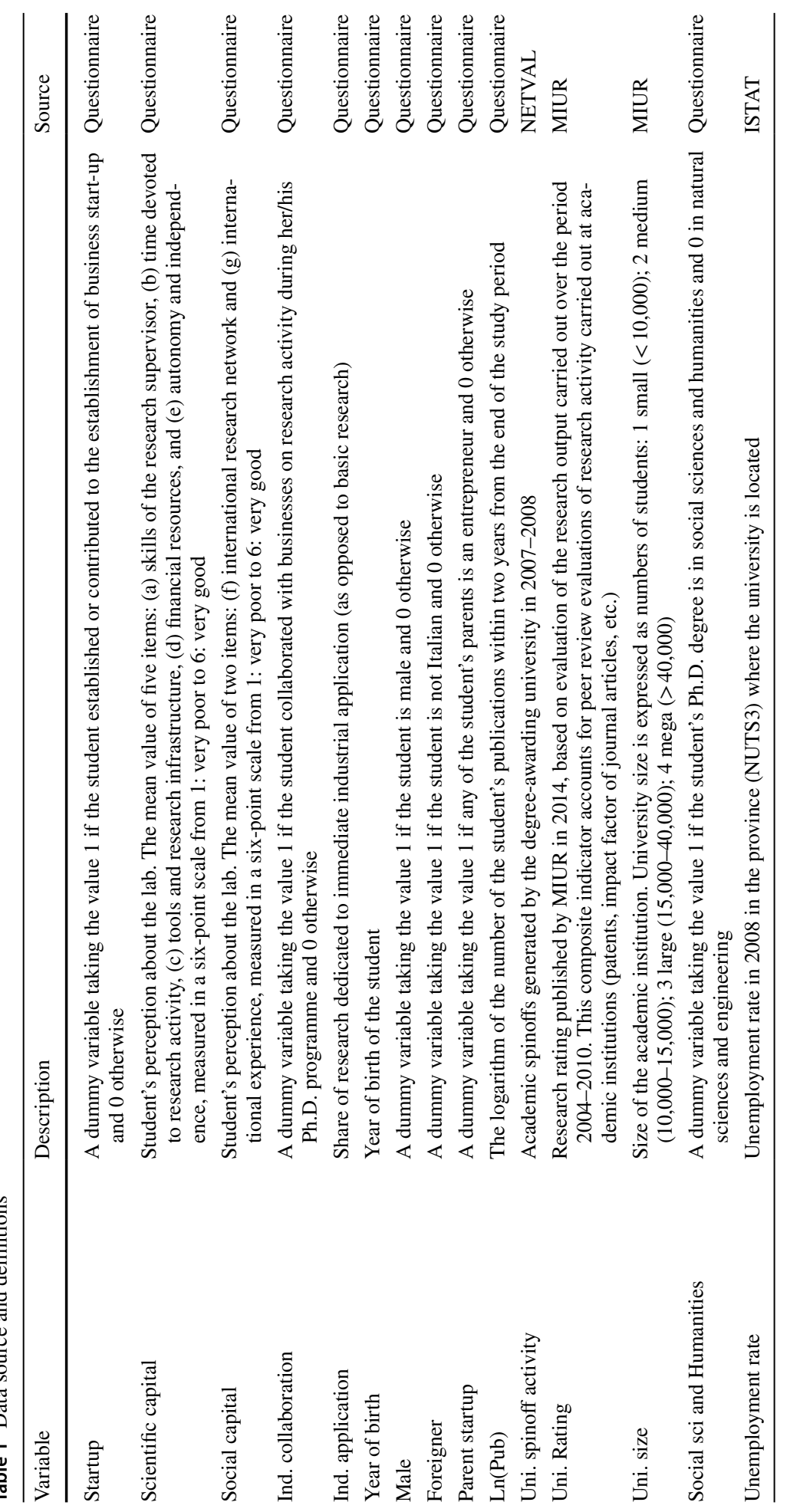




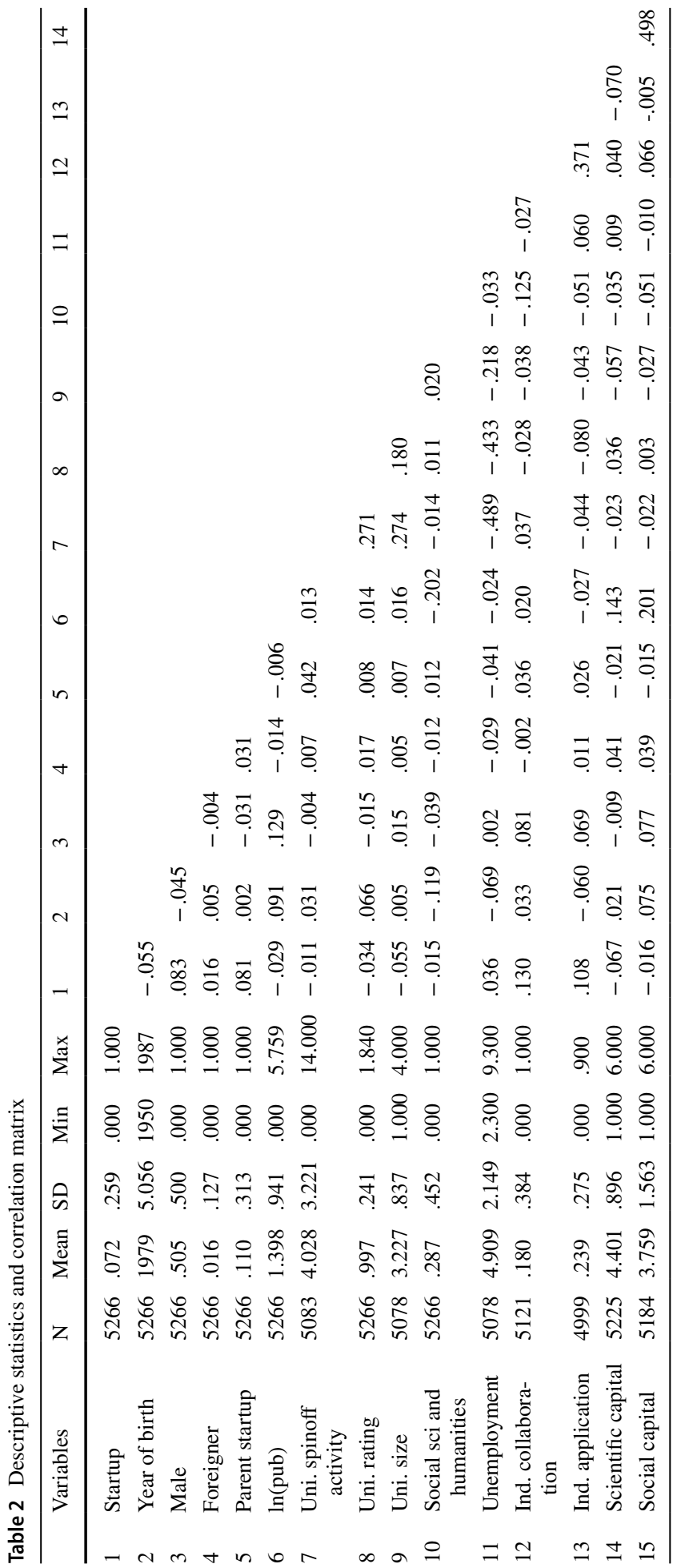




\section{Results}

\subsection{Determinants of Ph.D. entrepreneurship}

First, we examine the probability of Ph.D. graduates' becoming entrepreneurs (startup) by logit regressions and find that lab capitals and business experience affect Ph.D. entrepreneurship.

Table $3 \mathrm{a}$ presents the base model with estimated marginal effects at the mean values of the independent variables. ${ }^{3}$ Model 1 includes only control variables and Models 2 and 3 add key independent variables. First, we find a direct effect of business experience. Model 2 suggests that industry collaboration increases the probability of startup (discrete change $=0.074, p<0.001)$ and Model 3 also suggests that industry application leads to startup (marginal effect $=0.062, p<0.001) .{ }^{4}$ Therefore, students' engagement in real-world scenarios and the application of their research in a business context have a positive impact on their choice to become entrepreneurs, supporting Hypothesis 1.

Second, we find a direct effect of lab scientific capital on students' decision to become entrepreneurs. Having access to scientific capital significantly decreases the probability of startup (Model 2: marginal effect $=-0.017, p<0.001$, Model 3: marginal effect $=-0.015$, $p<0.001)$. Although lab scientific capital could have both positive and negative effects on $\mathrm{Ph} . \mathrm{D}$. entrepreneurship, our result in the context of $\mathrm{Ph} . \mathrm{D}$. studies suggests that scientific capital facilitate progression in the academic career ladder (Long et al. 1979; Miller et al. 2005) to a greater extent than it may contribute to entrepreneurial processes (e.g., Muscio et al. 2013).

Third, we did not find a significant direct effect of lab social capital on Ph.D. entrepreneurship. ${ }^{5}$ While lab social capital can open up entrepreneurial opportunities (e.g., Knight 2015; Ardichvili and Cardozo 2000), it can also lead to broader career alternatives (Edler et al. 2011; Knight 2004). Our result implies that neither of these effects clearly surpass the other in the case of Ph.D. entrepreneurship.

Concerning the control variables, the effects of individual-level variables are consistent with previous findings on academic entrepreneurship by established academics (Krabel and Mueller 2009). First, we find a significant age effect, with younger Ph.D. students being more likely to become entrepreneurs (Model 1: marginal effect $=-0.002$, $p<0.001$ ). ${ }^{6}$ Second, in line with the previous literature (Bienkowska et al. 2016; Conti and Visentin 2015; Parker et al. 2017), male students than females have a higher probability of becoming entrepreneurs (Model 1: discrete change $=0.042, p<0.001$ ). Finally, the publication performance is negatively associated with $\mathrm{Ph} . \mathrm{D}$. entrepreneurship (Model 1: marginal effect $=-0.009, p<0.05$ ). This may be due to a trade-off between entrepreneurship and scientific performance (e.g., Walter et al. 2013), as entrepreneurial efforts and protection of intellectual properties can restrict information disclosure, thus compromising publication performance.

As to the university-level factors, the result shows that smaller universities are more supportive to Ph.D. entrepreneurship (Model 1: marginal effect $=-0.014, p<0.001$ ),

\footnotetext{
3 The sample size differs between the models because of missing data in some variables. We also ran the models with the maximum common sample to confirm the results.

4 To avoid multicollinearity, we test industry collaboration and industry application in separate models. We find significant effects of both variables even when we include them in a single model.

5 We also tested the effects of lab scientific capital and social capital in separate models, as the result can be affected by collinearity of the variables and found consistent results.

${ }^{6}$ We also controlled for the cohort of Ph.D. students and find the same age effect but little cohort effect.
} 
Table 3 Prediction of Ph.D. startup

(A) Base model (marginal effects)

\begin{tabular}{|c|c|c|c|c|c|c|}
\hline & Model 1 & & Model 2 & & Model 3 & \\
\hline Year of birth & $-.002 * * *$ & $(.001)$ & $-.002 * * *$ & $(.001)$ & $-.002 * *$ & $(.001)$ \\
\hline Male $^{\mathrm{a}}$ & $.042 * * *$ & $(.007)$ & $.034 * * *$ & $(.007)$ & $.035 * * *$ & $(.007)$ \\
\hline Foreigner $^{\mathrm{a}}$ & .037 & $(.033)$ & .025 & $(.032)$ & .046 & $(.036)$ \\
\hline Parent startup ${ }^{a}$ & $.063 * * *$ & $(.014)$ & $.056 * * *$ & $(.014)$ & $.058 * * *$ & $(.014)$ \\
\hline $\ln (\mathrm{pub})$ & $-.009 *$ & $(.004)$ & $-.007+$ & $(.003)$ & $-.006+$ & $(.004)$ \\
\hline Uni. spinoff activity & .001 & $(.001)$ & .001 & $(.001)$ & .001 & $(.001)$ \\
\hline Uni. rating & -.015 & $(.015)$ & -.012 & $(.014)$ & -.006 & $(.015)$ \\
\hline Uni. size & $-.014 * * *$ & $(.004)$ & $-.012 * *$ & $(.004)$ & $-.013 * * *$ & $(.004)$ \\
\hline Social sci and Humanities ${ }^{a}$ & $-.013+$ & $(.007)$ & -.005 & $(.007)$ & -.007 & $(.008)$ \\
\hline Unemployment & .003 & $(.002)$ & .003 & $(.002)$ & .003 & $(.002)$ \\
\hline Scientific capital & & & $-.017 * * *$ & $(.004)$ & $-.015^{* * *}$ & $(.004)$ \\
\hline Social capital & & & .002 & $(.002)$ & .003 & $(.002)$ \\
\hline Ind. collab ${ }^{\mathrm{a}}$ & & & $.074 * * *$ & $(.011)$ & & \\
\hline Ind. Appl & & & & & $.062 * * *$ & $(.011)$ \\
\hline Chi-squared stat & $106.116^{* * *}$ & & $182.638^{* * * *}$ & & $147.056 * * *$ & \\
\hline Log likelihood & -1267.931 & & -1184.993 & & -1182.476 & \\
\hline $\mathrm{N}$ & 5055 & & 4868 & & 4768 & \\
\hline
\end{tabular}

(B) Interaction effect (coefficients)

\begin{tabular}{|c|c|c|c|c|c|c|c|c|}
\hline & Model 1 & & Model 2 & & Model 3 & & Model 4 & \\
\hline Scientific capital & $-.395 * * *$ & $(.077)$ & $-.302 * * *$ & $(.068)$ & $-.411 * * *$ & $(.091)$ & $-.271 * * *$ & $(.069)$ \\
\hline Social capital & .037 & $(.042)$ & -.010 & $(.049)$ & .046 & $(.042)$ & -.055 & $(.056)$ \\
\hline Ind. collab & -.334 & $(.580)$ & .430 & $(.328)$ & & & & \\
\hline Ind. appl & & & & & -.675 & $(.756)$ & -.097 & $(.466)$ \\
\hline $\begin{array}{l}\text { Scientific capi- } \\
\text { tal } \times \text { Ind. collab }\end{array}$ & $.307 *$ & $(.131)$ & & & & & & \\
\hline $\begin{array}{l}\text { Social capital } \times \text { Ind. } \\
\text { collab }\end{array}$ & & & $.144+$ & $(.079)$ & & & & \\
\hline $\begin{array}{l}\text { Scientific capi- } \\
\text { tal } \times \text { Ind. appl }\end{array}$ & & & & & $.422 *$ & $(.177)$ & & \\
\hline $\begin{array}{l}\text { Social capital } \times \text { Ind. } \\
\text { appl }\end{array}$ & & & & & & & $.320 * *$ & $(.117)$ \\
\hline Chi-squared stat & $188.186^{* * * *}$ & & $186.047 * * *$ & & $152.783^{* * * *}$ & & $154.632 * * *$ & \\
\hline Log likelihood & -1182.219 & & -1183.289 & & -1179.613 & & -1178.689 & \\
\hline $\mathrm{N}$ & 4868 & & 4868 & & 4768 & & 4768 & \\
\hline
\end{tabular}

Logit regressions. Two-tailed test

${ }^{\dagger} p<0.1 ;{ }^{*} p<0.05 ;{ }^{* *} p<0.01,{ }^{* * *} p<0.001$

(A) Marginal effects at the means (standard errors in parentheses). ${ }^{\text {a }}$ The discrete change from the base level is indicated for dummy variables. (B) Unstandardised coefficients (standard errors in parentheses). Only the focal independent variables are presented for parsimony. The complete results are given in Online Supplement

while institutional research performance (uni. rating) has no significant effect on startup creation in line with the literature on academic spinoffs (Landry et al. 2006; Muscio 
(a) Scientific capital * Industry collaboration Adjusted Predictions with $95 \% \mathrm{Cls}$

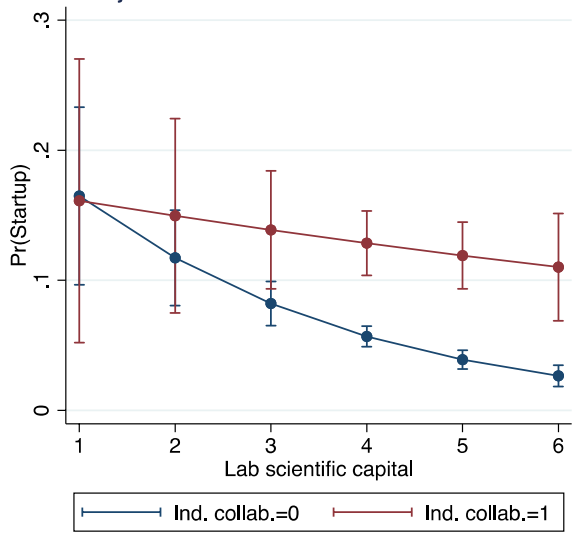

(c) Scientific capital * Industry application

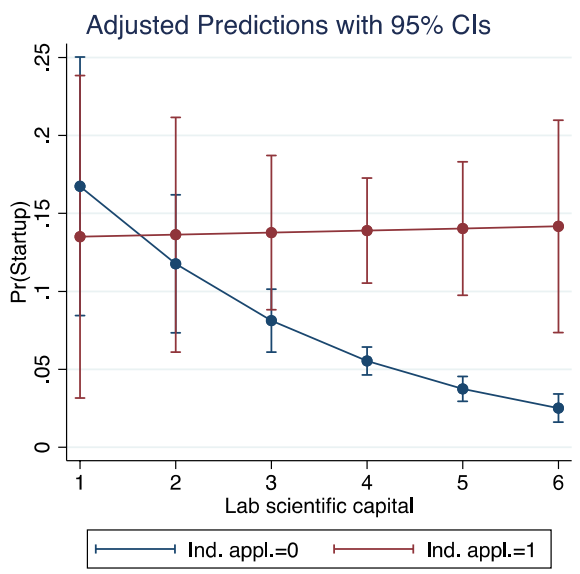

(b) Social capital * Industry collaboration

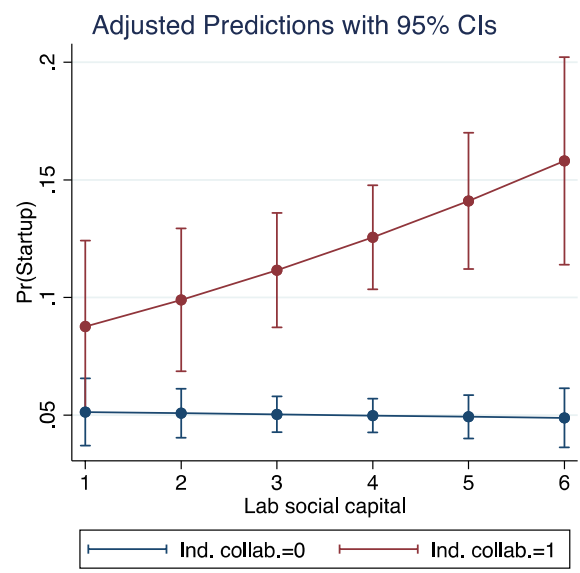

(d) Social capital * Industry application

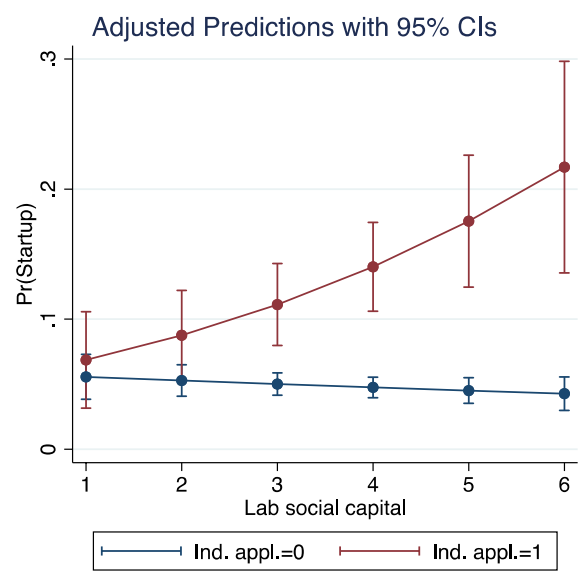

Fig. 2 Interaction effect of lab capital and entrepreneurial experience. Notes The predicted probability of Ph.D. startup with 95\% confidence intervals. Estimations are based on Table 3B (a: Model 1, b: Model 2, c: Model 3, d: Model 4) with the mean values of all independent variables except for the focal independent variables

et al. 2016; Ramaciotti and Rizzo 2015). Unlike previous empirical findings (Degroof and Roberts 2004; Muscio and Ramaciotti 2019), we do not find a strong evidence that economically underdeveloped areas (i.e., higher unemployment) are associated with Ph.D. entrepreneurship.

Next, to test Hypotheses 2 and 3, we run regression models including interaction terms between business experience and lab capitals (Table 3b). Models 2 and 4 test the interaction between social capital and business experience, finding positive moderating effects (Model 2: $\mathrm{b}=0.144, p<0.1$; Model 4: $\mathrm{b}=0.320, p<0.01$ ). Figures $2 \mathrm{~b}$, d graphically illustrate these moderating effects. The figures show that social capital has almost no effect on startup if business experience is non-existent. However, if students are given business experience, social capital significantly increases the probability of startup. This result suggests 
that collaboration with industry and industrial application enhance the role of social capital in shaping students' entrepreneurship, supporting Hypothesis 3.

Models 1 and 3 then test the interaction between scientific capital and business experience and find positive interaction effects (Model 1: $b=0.307, p<0.05$; Model 3: $b=0.422$, $p<0.05)$. This is supportive to Hypothesis 2. Figure 2a, c indicate that in the absence of business experience, higher scientific capital significantly decreases the likelihood of startup. However, this negative effect is mitigated or disappears if students are given business experience. We do not nonetheless see that scientific capital increases the probability of $\mathrm{Ph} . \mathrm{D}$. entrepreneurship even with business experience. This result hints that scientific capital is detrimental to Ph.D. entrepreneurship, which is further investigated in the next section.

\subsection{Different types of Ph.D. entrepreneurship}

As we find that not all startups by Ph.D. students originate from university labs, we investigate the determinants of different types of startup (career option). Namely we distinguish startups associated with universities and startups not associated, and the former group is further split into the graduates who maintained academic employment and those who did not. We also include other career options, with academic employment as the base category. Table $4 \mathrm{a}$ presents the result of multinomial logit regressions with estimated marginal effects.

Consistent with Hypothesis 1, business experience shows significantly positive effects on university-related startup, especially on university-related startup with continuous academic employment (industry collaboration: discrete change $=0.032, p<0.001$; industry application: marginal effect $=0.019, p<0.01$ ). This suggests that Ph.D. entrepreneurship that is based on university resources is conditioned on business experience in the lab. On the other hand, no significant effect is observed in the case of university-unrelated startup. This might imply that business experience is domain-specific, and that research-based business experience is required for university-related startup.

Concerning the lab capital variables, the result shows a significantly negative effect of scientific capital on university-unrelated startup (marginal effect $=-0.009, p<0.001$ ) but not on university-related startup. Thus, a trade-off between scientific activities and entrepreneurial activities (e.g., Walter et al. 2013) is observed only if the two activities are unrelated, whereas the trade-off is minor or non-existent when they are related. On the other hand, the direct effect of social capital on any startup type is insignificant or weak.

As to the control variables, qualitatively similar effects are indicated across different startup types, but differences are found in a few variables. First, the negative age effect is only observed for university-unrelated startup (marginal effect $=-0.001, p<0.01$ ). In other words, age disadvantage does not exist in the case of university-related startup. Second, the unemployment rate has a positive effect only on university-unrelated startup (marginal effect $=0.003, p<0.05$ ). This suggests that lack of employment is compensated by entrepreneurship, as literature has suggested (Muscio and Ramaciotti 2019), but contribution of academic training may not be clear. Third, startup types differ between scientific fields; namely, university-unrelated startup is more common (discrete change $=0.013$, $p<0.05$ ) but university-related startup is less common (discrete change $=0.005, p<0.05$ ) in social sciences and humanities than in natural sciences and engineering. This is perhaps explained by business consultation typically started by graduates in the former.

Table $4 \mathrm{~b}$ tests the interaction effect of business experience and lab capitals. First, Model 1 shows a positive interaction effect of industry collaboration and scientific capital on university-unrelated startup $(b=0.503, p<0.05)$. A graphical illustration indicates that 


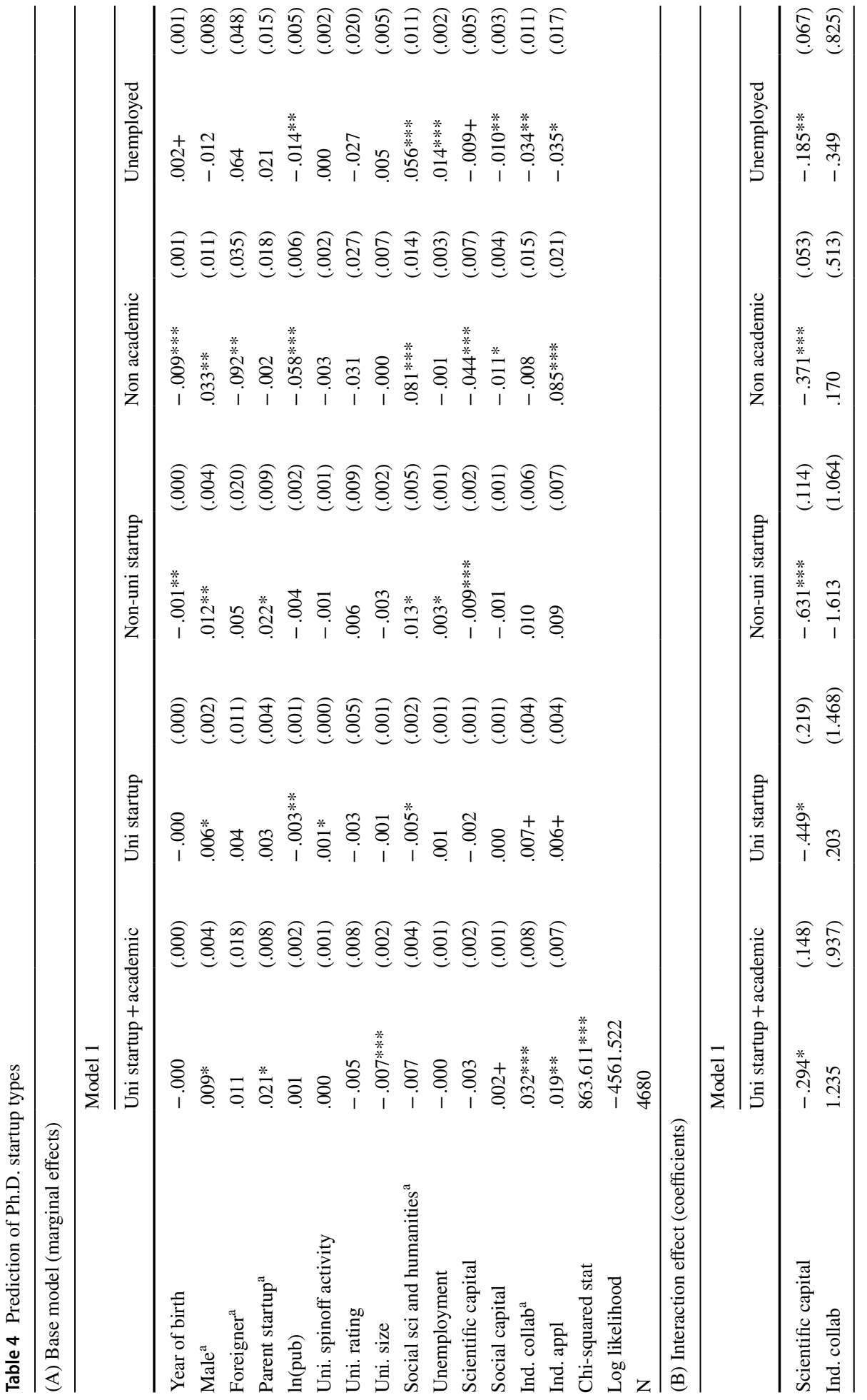




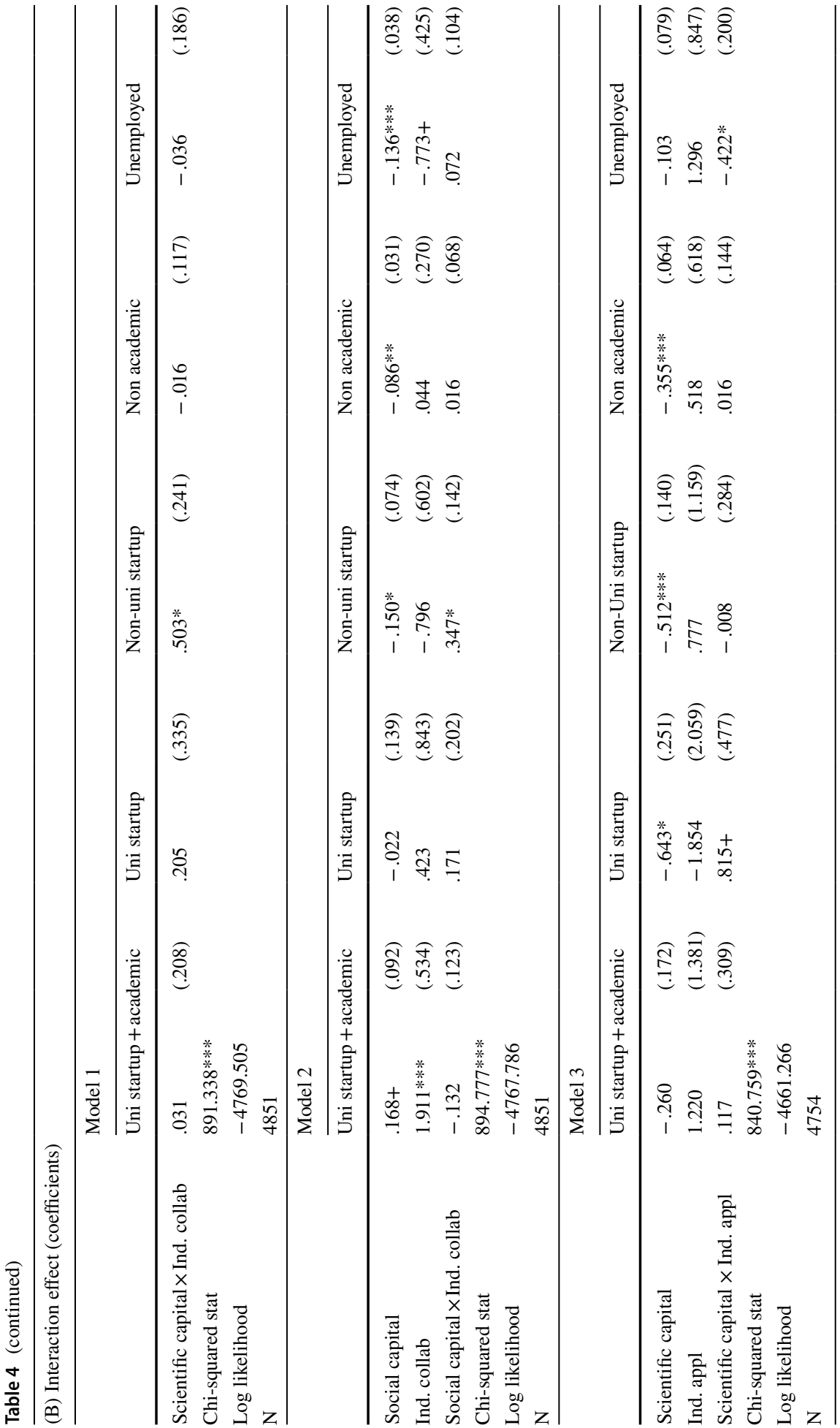




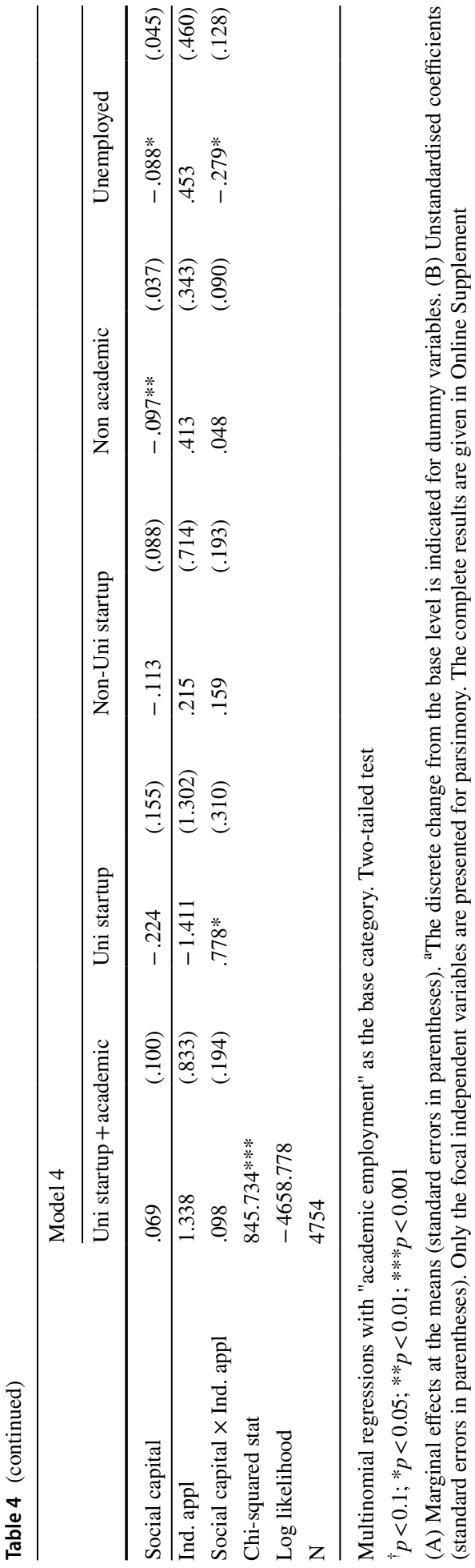


(a) Scientific capital * Industry collaboration

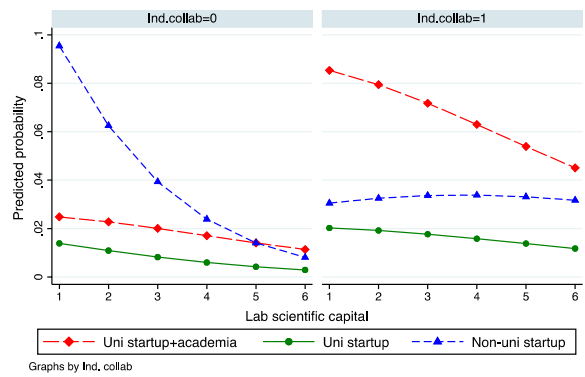

(c) Scientific capital * Industry application

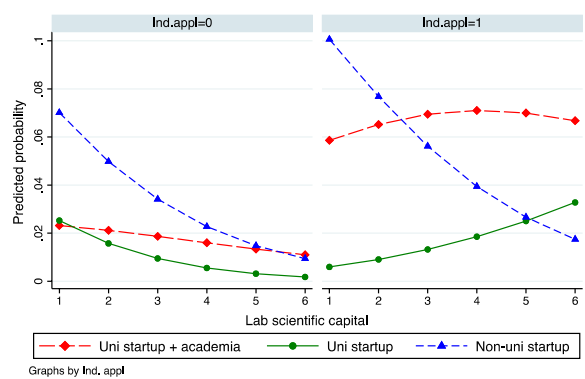

(b) Social capital * Industry collaboration

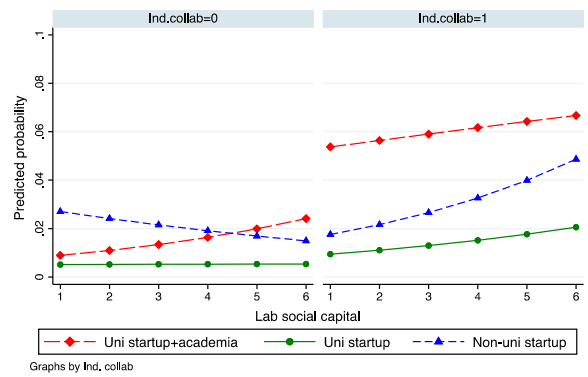

(d) Social capital * Industry application

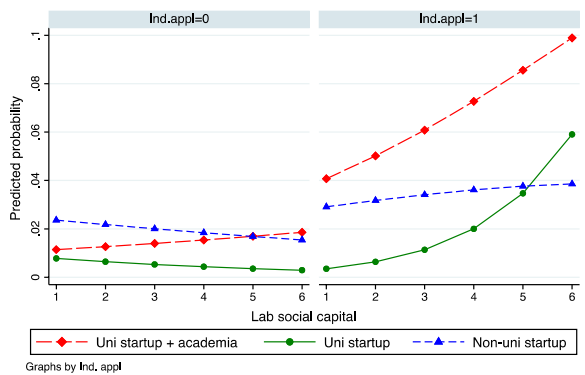

Fig. 3 Interaction effect of lab capital and entrepreneurial experience. Notes The predicted probabilities of three startup options are presented. Estimations are based on Table 4B (a: Model 1, b: Model 2, c: Model 3, d: Model 4) with the mean values of all independent variables except for the focal independent variables. The probabilities of academic and non-academic employment and unemployment are omitted

scientific capital has a negative effect on university-unrelated startup only if students do not have industry collaboration (Fig. 3a). Thus, Ph.D. students are more likely to start university-unrelated startup when they had neither business experience nor scientific capital. Model 3 shows a weakly positive interaction effect of industry application and scientific capital on university-related startup $(b=0.815, p<0.1)$. Figure $3 c$ indicates that scientific capital increases the probability of startup only if they engage in industrially applicable research. This is consistent with our expectation in Hypothesis 2.

Similarly, Model 2 presents a positive interaction effect of industry collaboration and social capital on university-unrelated startup $(b=0.347, p<0.05)$. Figure $3 b$ shows that high social capital decreases startup if students do not have industry collaboration, but that social capital increases startup if students do have industry collaboration. Model 4 shows a positive interaction effect between industry application and social capital on university-related startup $(b=0.778, p<0.05)$, and Fig. 3d illustrates that social capital leads to startup only if students engage in industrially applicable research. This is consistent with Hypothesis 3.

Unlike in the previous section, we find that the moderation effects of industry collaboration (Models 1 and 2) and industry application (Models 3 and 4) work on different startup types. Human interaction through collaboration appears to be more relevant when $\mathrm{Ph} . \mathrm{D}$. students start businesses not originating from universities. On the other hand, interaction in the knowledge space through applied research is more important when students start businesses originating from universities. 


\subsection{Robustness check}

A potential concern in our empirical approach is selection bias. For example, students who intended to start up their own businesses might have chosen a lab with more opportunities of business experience, though we believe that the majority of Ph.D. students aimed to find academic employment after graduation (Mangematin 2000). In addition, students with high latent research skills, who thus are likely to find academic employment, might be recruited by labs with high scientific capital. Although our empirical setup does not allow us to directly control for such factors, we have a few proxy measures. For a subset of our sample, information about students' general risk orientation (risk orientation) and students' undergraduate academic score (undergrad score) are available. Controlling for these variables, Appendix 2 runs the same set of regressions, finding consistent results.

The prior literature on entrepreneurship tends to focus on narrower scientific fields, often excluding social sciences and humanities. The coverage of whole fields is an advantage of this study, as field difference is of both practical and scholarly interest. Thus, we split our sample into (1) natural sciences and engineering and (2) social sciences and humanities, and find a few differences between the two groups (Appendix 3). As to the direct effect of business experience, it appears that industrial application of students' research is less relevant in social sciences and humanities (Models 1 vs. 6). This suggests that Ph.D. entrepreneurship in the fields less directly depends on research output. This is consistent with the fact that Ph.D. entrepreneurship in the field is often university-unrelated (Table 4a). In contrast, Ph.D. since entrepreneurship in natural sciences and engineering usually depends on the knowledge itself, the applicability of research is crucial. On the other hand, the direct effect of industry collaboration is significantly positive in both fields, which implies that human interaction is critical regardless of scientific fields. As to the interaction effects, accordingly, both scientific and social capitals are moderated mainly by industry applicability in natural sciences and engineering (Models 4 and 5) and by industry collaboration in social sciences and humanities (Models 9 and 10).

\section{Concluding remarks}

This paper aims to improve our understanding of the impact of the academic environment $\mathrm{Ph} . \mathrm{D}$. students engage with during their training period and their decision to become entrepreneurs. Our analysis based on a survey of Italian Ph.D. students offer several key findings.

First of all, we find that a substantial proportion of Ph.D. graduates choose entrepreneurial careers, and approximately half of the startups are based on university technologies and know-how. Thus, it seems that Ph.D. training does contribute to knowledge transfer to the society through entrepreneurship. However, as the other half of startup is not associated with universities, the impact of Ph.D. entrepreneurship as a means of knowledge transfer must be carefully evaluated. We also find that three quarters of university-related startup are made by students who also maintained academic employment. This suggests that Ph.D. students do not necessarily have to take a risk of entrepreneurship entirely privately, and the Italian universities have already institutionalised a safety net by providing adjunct positions to student entrepreneurs or allowing postdocs to engage in startup activities.

The paper then investigates the contribution of the academic environment to Ph.D. entrepreneurship, by focusing on the local lab environment where students are affiliated. In particular, we examine the scientific and social capitals as well as business experience available for students. The result shows that Ph.D. entrepreneurship is driven by business experience during the training period, particularly when they start university-related 
businesses, as opposed to unrelated businesses. Second, the result suggests that scientific capital is negatively associated with students' startup activities that are unrelated to university research. This result is consistent with the argument that scientific excellence and entrepreneurial activities are in conflict (Baldini 2010; Muscio et al. 2016; Ramaciotti and Rizzo 2015), but this is true only if startup is not based on university research. Third, high scientific and social capitals are associated with Ph.D. entrepreneurship only if students are given business experience. In particular, students trained under high lab capitals and experience of industrially applicable research tend to engage in university-related startup.

These results have a few theoretical implications. First, Ph.D. students are an important source of entrepreneurship, on top of faculty entrepreneurship, though the prior literature has focused mostly on the latter (Astebro et al. 2012; Hayter et al. 2017; Shah and Pahnke 2014). Overall, we see similarities in the determinants of Ph.D. entrepreneurship and those of faculty entrepreneurship (e.g., business experience). However, our results also suggest peculiarities of Ph.D. entrepreneurship (e.g., the negative effect of scientific capital). Thus, the increasing phenomenon of Ph.D. entrepreneurship should be further investigated, with the specificity of the student status and the career stage taken into consideration. Second, while previous literature has mostly investigated institution-wide environment as determinants of academic entrepreneurship (Muscio and Ramaciotti 2019), we demonstrate that students are strongly influenced by a local context of laboratories and student-supervisor relationships. The general importance of local research environment has been suggested in literature (Blau 1994; Latour and Woolgar 1979; Knorr-Cetina 1999; Shibayama et al. 2015), but it can be of particular relevance for the entrepreneurship by students who might have limited ties beyond the lab environment. Future research should incorporate this multi-level structure of academic institutions. Third, Ph.D. entrepreneurship can be diverse in its forms - some based on university research and others not-and we find that they are driven by different factors. Students can contribute to knowledge transfer to the society through university-related startup but those starting up unrelated businesses may not. Therefore, these different types should be carefully distinguished and investigated.

Our results provide some policy insights. First of all, we provide evidence that Ph.D. entrepreneurship, at least in the Italian context, is not an exception both in terms of economic impact and as a form of academic engagement with industry; $6.7 \%$ of graduates pursue entrepreneurship careers, while Italy stands at the bottom of world rankings for the entrepreneurship rate with a rate of $1.3 \%$ according to the Global Entrepreneurship Monitor. This provides new insights into the magnitude of the impact that universities can have on the promotion of economic development, strengthening the argument that universities can be important stakeholders in regional economic growth. While technology transfer policies so far have paid little attention to Ph.D. entrepreneurship, our findings make a case for promotion of an entrepreneurial university model beyond the framework currently adopted in many European and US institutions. Second, our result demonstrates that students' engagement in real-world scenarios and the application of their research results in a business context have a significant impact on the chance of students becoming entrepreneurs. Thus, developing local environment favourable to entrepreneurship can make a difference in startup creation. Third, the lab environment factors have mixed effects on Ph.D. entrepreneurship in terms of the direction of the effects as well as resulting types of entrepreneurship. Investment in Ph.D. programmes can improve the institutional capability to transfer knowledge through entrepreneurship but can end in an opposite result. Therefore, as suggested in Muscio and Ramaciotti (2019), policies for academic entrepreneurship must be carefully designed to direct students towards effective career options. Our results also adds a new perspective to the value of Ph.D. training. The cost-effectiveness of Ph.D. 
training - whether the benefits of training outweigh the costs - has been debated (Pedersen 2016). A recent trend is that Ph.D. studies should aim to train for more than research excellence, including generic skills such as project management and problem solving. Indeed, industries consider $\mathrm{Ph}$.D. holders skilled and creative human capital that provide access to innovative thinking and knowledge transfer (Park 2007). We demonstrate that Ph.D. entrepreneurship is another route for the academic sector to contribute to the wider society.

Despite relevant theoretical and policy implications, this study faces some important limitations, the most important being the cross-sectional nature of the database, which reduces the ability to check any cause-effect implication between lab environment and Ph.D. entrepreneurship. Second, this study does not consider the long-term outcome of Ph.D. entrepreneurship (e.g., growth, economic returns), which should be evaluated to design policies. Third, the sample specificity limits the generalisability of our findings. The operation of Ph.D. training as well as career systems differ between countries, which should influence the rationale behind students' career decisions.

\section{Appendix 1}

See Table 5 .

Table 5 Factor analysis of lab capital

\begin{tabular}{llll}
\hline & & $\begin{array}{l}\text { Factor 1 } \\
\text { (Scientific) }\end{array}$ & $\begin{array}{l}\text { Factor 2 } \\
\text { (Social) }\end{array}$ \\
\hline a & Skills of the research supervisor & $\mathbf{0 . 6 2 5}$ & 0.188 \\
b & Time devoted to research activity & $\mathbf{0 . 7 2 0}$ & 0.103 \\
c & Tools and research infrastructure & $\mathbf{0 . 7 2 8}$ & 0.304 \\
d & Financial resources & $\mathbf{0 . 6 0 9}$ & 0.369 \\
e & Autonomy / Independence & $\mathbf{0 . 5 9 2}$ & 0.189 \\
$\mathrm{f}$ & International research network & 0.307 & $\mathbf{0 . 8 6 6}$ \\
g & International experience & 0.051 & $\mathbf{0 . 9 3 3}$ \\
& Proportion & 0.323 & 0.276 \\
\hline
\end{tabular}

Principal-component factor analysis with varimax rotation. Factor loadings greater than 0.5 are indicated in bold italic. The two factors have eigenvalues greater than one. Kaiser-Meyer-Olkin (KMO) measure is 0.76

\section{Appendix 2}

See Table 66. 


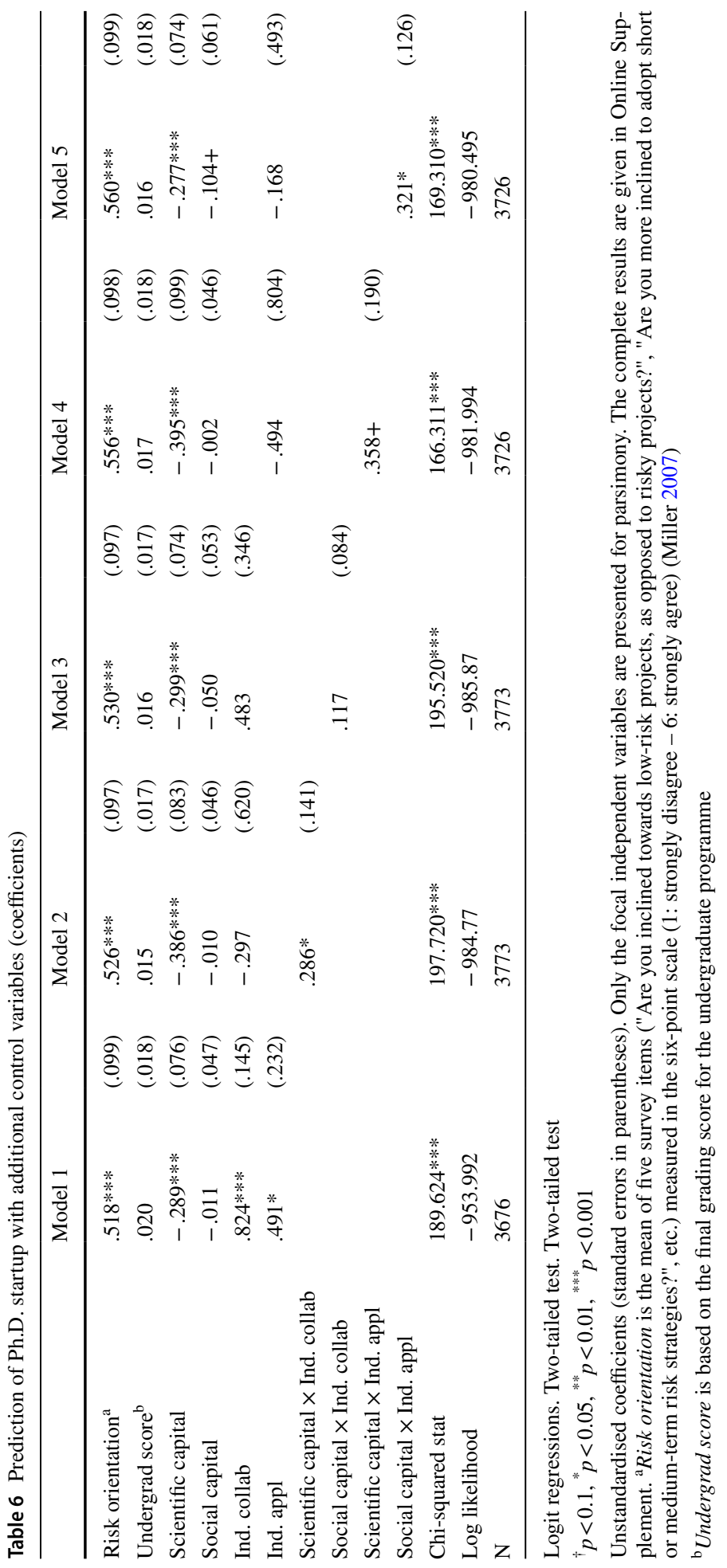




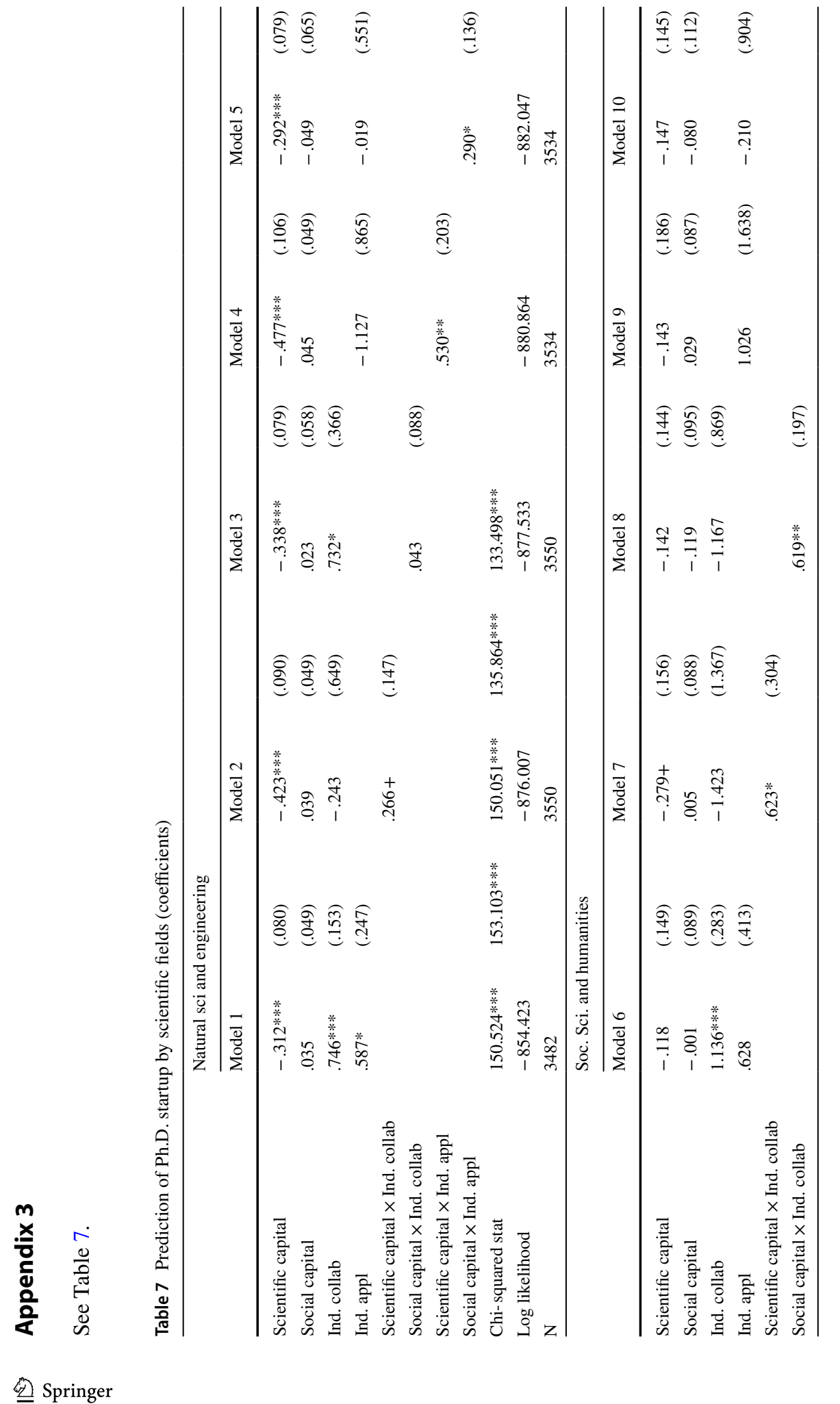




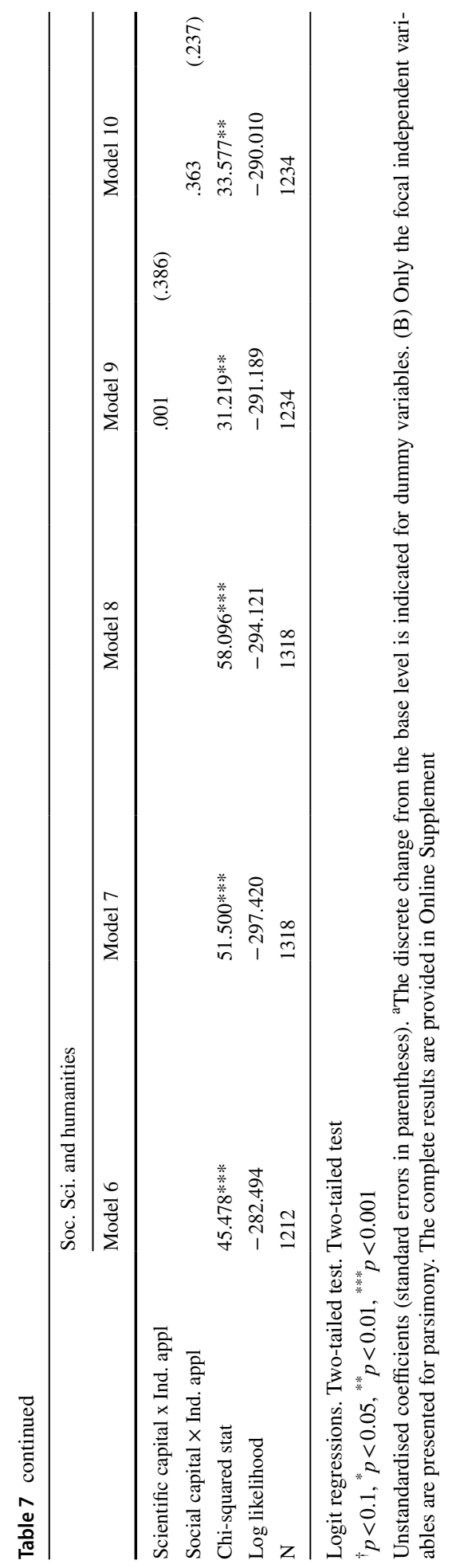


Supplementary Information The online version contains supplementary material available at. https://doi. org/10.1007/s10961-020-09841-2.

Acknowledgements The authors are grateful to Ugo Rizzo for his help with the data cleaning process and to CINECA for the questionnaire administration and data collection.

Funding Open Access funding provided by Lund University.

Open Access This article is licensed under a Creative Commons Attribution 4.0 International License, which permits use, sharing, adaptation, distribution and reproduction in any medium or format, as long as you give appropriate credit to the original author(s) and the source, provide a link to the Creative Commons licence, and indicate if changes were made. The images or other third party material in this article are included in the article's Creative Commons licence, unless indicated otherwise in a credit line to the material. If material is not included in the article's Creative Commons licence and your intended use is not permitted by statutory regulation or exceeds the permitted use, you will need to obtain permission directly from the copyright holder. To view a copy of this licence, visit http://creativecommons.org/licenses/by/4.0/.

\section{References}

Abreu, M., \& Grinevich, V. (2013). The nature of academic entrepreneurship in the UK: Widening the focus on entrepreneurial activities. Research Policy, 42, 408-422.

Altbach, P. G., \& Knight, J. (2007). The internationalization of higher education: Motivations and realities. Journal of Studies in International Education, 11(3-4), 290-305.

Ardichvili, A., \& Cardozo, R. N. (2000). A model of the entrepreneurial opportunity recognition process. Journal of Enterprising Culture, 08, 103-119.

Arenius, P., \& De Clercq, D. (2005). A network-based approach on opportunity recognition. Small Business Economics, 24(3), 249-265.

Åstebro, T., Bazzazian, N., \& Braguinsky, S. (2012). Startups by recent university graduates and their faculty: Implications for university entrepreneurship policy. Research Policy, 41(4), 663-677.

Autio, E., Kenney, M., Mustar, P., Siegel, D., \& Wright, M. (2014). Entrepreneurial innovation: The importance of context. Research Policy, 43, 1097-1108.

Azoulay, P., Ding, W., \& Stuart, T. (2007). The determinants of faculty patenting behavior: Demographics or opportunities? Journal of Economic Behavior and Organization, 63, 599-623.

Azoulay, P., Ding, W., \& Stuart, T. (2009). The impact of academic patenting on the rate, quality and direction of (public) research output. The Journal of Industrial Economics, 57, 637-676.

Baldini, N. (2010). University spin-offs and their environment. Technology Analysis and Strategic Management, 22, 859-876.

Bergmann, H., Hundt, C., \& Sternberg, R. (2016). What makes student entrepreneurs? On the relevance (and irrelevance) of the university and the regional context for student start-ups. Small Business Economics, 47, 53-76.

Bienkowska, D., Klofsten, M., \& Rasmussen, E. (2016). PhD students in the entrepreneurial universityPerceived support for academic entrepreneurship. European Journal of Education, 51(1), 56-72.

Blau, P. M. (1994). The organization of academic work. New Jersey: Transaction Publishers.

Blumenthal, D., Campbell, E. G., Causino, N., \& Seashore Louis, K. (1996). Participation of life-science faculty in research relationships with industry. New England Journal of Medicine, 335(23), 1734-1739.

Brindley, C., \& Ritchie, B. (2000). Undergraduates and small and medium-sized enterprises: Opportunities for a symbiotic partnership? Education and Training, 42(9), 509-517.

Castillo Holley, A., \& Watson, J. (2017). Academic entrepreneurial behavior: Birds of more than one feather. Technovation, 64-65, 50-57.

Clark, B. R. (1998). Creating entrepreneurial universities: Organizational pathways of transformation. New York: Pergamon.

Colombo, M. G., \& Piva, E. (2012). Firms' genetic characteristics and competence-enlarging strategies: A comparison between academic and non-academic high-tech start-ups. Research Policy, 41, 79-92.

Conti, A., \& Visentin, F. (2015). A revealed preference analysis of Ph.D. students' choices over employment outcomes. Research Policy, 44, 1931-1947. 
D’Este, P., Mahdi, S., Neely, A., \& Rentocchini, F. (2012). Inventors and entrepreneurs in academia: What types of skills and experience matter? Technovation, 32(5), 293-303.

D’Este, P., \& Perkmann, M. (2011). Why do academics engage with industry? The entrepreneurial university and individual motivations. Journal of Technology Transfer, 36, 316-339.

Degroof, J. J., \& Roberts, E. B. (2004). Overcoming weak entrepreneurial infrastructures for academic spinoff ventures. The Journal of Technology Transfer, 29, 327-352.

Dooley, L., \& Kenny, B. (2015). Research collaboration and commercialization: the Ph.D. candidate perspective. Industry and Higher Education, 29, 93-110.

Edler, J., Fier, H., \& Grimpe, C. (2011). International scientist mobility and the locus of knowledge and technology transfer. Research Policy, 40(6), 791-805.

Etzkowitz, H., Webster, A., Gebhardt, C., \& Terra, B. (2000). The future of the university and the university of the future: Evolution of ivory tower to entrepreneurial paradigm. Research Policy, 29, 313-330.

European Commission. (2010). Monitoring industrial research: The 2010 EU Industrial R\&D Investment Scoreboard. Seville.

Fabrizio, K. R., \& Di Minin, A. (2008). Commercializing the laboratory: Faculty patenting and the open science environment. Research Policy, 37(5), 914-931.

Felicio, J. A., Caldeirihna, V., \& Ribeiro-Navarrete, B. (2015). Corporate and individual global mind-set and internationalization of European SMEs. Journal of Business Research, 68, 797-802.

Fini, R., Lacetera, N., \& Shane, S. (2010). Inside or outside the IP system? Business creation in academia. Research Policy, 39(8), 1060-1069.

Fitzenberger, B., \& Schulze, U. (2014). Up or out: research incentives and career prospects of postdocs in Germany. German Economic Review, 15, 287-328.

Hayter, C. S., Lubynsky, R., \& Maroulis, S. (2017). Who is the academic entrepreneur? The role of graduate students in the development of university spinoffs. Journal of Technology Transfer, 42, 1237-1254.

Hayter, C. S., \& Parker, M. A. (2019). Factors that influence the transition of university postdocs to nonacademic scientific careers: An exploratory study. Research Policy, 48(3), 556-570.

Horta, H. (2010). The role of the state in the internationalization of universities in catching-up countries: An analysis of the Portuguese higher education system. Higher Education Policy, 23(1), 63-81.

Kessels, J., \& Kwakman, K. (2007). Interface: establishing knowledge networks between higher vocational education and business. Higher Education, 54(5), 689-703.

Kirchhoff, B. A., Newbert, S. L., Hasan, I., \& Armington, C. (2007). The influence of university R\&D expenditures on new business formations and employment growth. Entrepreneurship Theory and Practice, 31, 543-559.

Knight, J. (2004). Internationalization remodeled: Definition, approaches and rationales. Journal of Studies in International Education, 8(1), 5-31.

Knight, J. (2015). International universities: Misunderstanding and emerging models? Journal of Studies in International Education, 19(2), 107-121.

Knorr-Cetina, K. (1999). Epistemic cultures: How the sciences make knowledge. Cambridge, MA: Harvard University Press.

Krabel, S., \& Mueller, P. (2009). What drives scientists to start their own company? An empirical investigation of Max Planck Society scientists. Research Policy, 38, 947-956.

Landry, R., Amara, N., \& Rherrad, I. (2006). Why are some university researchers more likely to create spin-offs than others? Evidence from Canadian universities. Research Policy, 35, 1599-1615.

Landry, R., Saihi, M., Amara, N., \& Ouimet, M. (2010). Evidence on how academics manage their portfolio of knowledge transfer activities. Research Policy, 39, 1387-1403.

Latour, B., \& Woolgar, S. (1979). Laboratory life: The construction of scientific facts. Princeton, NJ: Princeton University Press.

Laudel, G. (2001). Collaboration, creativity and rewards: why and how scientists collaborate. International Journal of Technology Management, 22, 762-781.

Lester, S., \& Costley, C. (2010). Work-based learning at higher education level: Value, practice and critique. Studies in Higher Education, 35(5), 561-575.

Long, J. S., Allison, P. D., \& Mcginnis, R. (1979). Entrance into the academic career. American Sociological Review, 44, 816-830.

Lowe, R. A., \& Gonzalez-Brambila, C. (2007). Faculty entrepreneurs and research productivity. The Journal of Technology Transfer, 32, 173-194.

Mangematin, V. (2000). Phd job market: Professional trajectories and incentives during the phd. Research Policy, 29, 741-756.

Maresch, D., Harms, R., Kailer, N., \& Wimmer-Wurm, B. (2016). The impact of entrepreneurship education on the entrepreneurial intention of students in science and engineering versus business studies university programs. Technology Forecasting and Social Change, 104, 172-179. 
McCormack, J., Propper, C., \& Smith, S. (2014). Herding cats? Management and university performance. Economic Journal, 124, 534-564.

Miller, C. C., Glick, W. H., \& Cardinal, L. B. (2005). The allocation of prestigious positions in organizational science: Accumulative advantage, sponsored mobility, and contest mobility. Journal of Organizational Behavior, 26, 489-516.

Miller, K. D. (2007). Risk and rationality in entrepreneurial processes. Strategic Entrepreneurship Journal, 1, 57-74.

Minola, T., Donina, D., \& Meoli, M. (2016). Students climbing the entrepreneurial ladder: Does university internationalization pay off? Small Business Economics, 47, 565-587.

Muscio, A., Quaglione, D., \& Ramaciotti, L. (2016). The effects of university rules on spinoff creation: The case of academia in Italy. Research Policy, 45, 1386-1396.

Muscio, A., Quaglione, D., \& Vallanti, G. (2013). Does government funding complement or substitute private research funding to universities? Research Policy, 42, 63-75.

Muscio, A., \& Ramaciotti, L. (2018). Dataset from a qualitative survey on PhD entrepreneurship in Italy. Data in Brief, 18, 1272-1276.

Muscio, A., \& Ramaciotti, L. (2019). How does academia influence Ph.D. entrepreneurship? New insights on the entrepreneurial university. Technovation, 82-83, 16-24.

Muscio, A., \& Vallanti, G. (2014). Perceived obstacles to university-industry collaboration: Results from a qualitative survey of Italian Academic Departments. Industry and Innovation, 21, 410-429.

Olmos-Peñuela, J., Castro-Martínez, E., D’Este, P., \& D’Este, P. (2014). Knowledge transfer activities in social sciences and humanities: Explaining the interactions of research groups with non-academic agents. Research Policy, 43, 696-706.

Park, C. (2007). Redefining the Doctorate. The Higher Education Academy, discussion paper.

Parker, M., Hayter, C. S., Lauren, L., Mohammed, R., Link, A., Parker, M., et al. (2017). Barriers to academic entrepreneurship among women: A review of the constituent literatures. In A. N. Link (Ed.), Gender and Entrepreneurial Activity. Cheltenham: Edward Elgar Publishing.

Pedersen, H. S. (2016). Are PhDs winners or losers? Wage premiums for doctoral degrees in private sector employment. Higher Education, 71(2), 269-287.

Philpott, K., Dooley, L., O’Reilly, C., \& Lupton, G. (2011). The entrepreneurial university: Examining the underlying academic tensions. Technovation, 31(4), 161-170.

Powers, J. B., \& McDougall, P. (2005). Policy orientation effects on performance with licensing to start-ups and small companies. Research Policy, 34, 1028-1042.

Prodan, I., \& Drnovsek, M. (2010). Conceptualizing academic-entrepreneurial intentions: An empirical test. Technovation, 30, 332-347.

Puljak, L., \& Sharif, W. D. (2009). Postdocs' perceptions of work environment and career prospects at a US academic institution. Research Evaluation, 18, 411-415.

Ramaciotti, L., Muscio, A., \& Rizzo, U. (2017). The impact of hard and soft policy measures on new technology-based firms. Regional Studies, 51(4), 629-642.

Ramaciotti, L., \& Rizzo, U. (2015). The determinants of academic spin-offs creation by Italian universities. $R \& D$ Management, 45(5), 501-514.

Rasmussen, E., \& Borch, O. J. (2010). University capabilities in facilitating entrepreneurship: A longitudinal study of spin-off ventures at mid-range universities. Research Policy, 39, 602-612.

Rasmussen, E., \& Sorheim, R. (2006). Action-based entrepreneurship education. Technovation, 26, 185-194.

Ridder, A., \& van der Sijde, P. (2003). Raising awareness of entrepreneurship and e-commerce: A case study on student-entrepreneurship. International Journal of Entrepreneurship and Innovation Management, 3(5), 609-620.

Sauermann, H., \& Roach, M. (2016). Why pursue the postdoc path? Science, 352, 663-664.

Schiller, D., \& Diez, J. R. (2010). Local embeddedness of knowledge spillover agents: Empirical evidence from German star scientists. Papers in Regional Science, 89, 275-294.

Shah, S. K., \& Pahnke, E. C. (2014). Parting the ivory curtain: Understanding how universities support a diverse set of startups. Journal of Technology Transfer, 39, 780-792.

Shane, S., \& Venkataraman, S. (2000). The promise of entrepreneurship as a field of research. Academy Management Review, 25(1), 217-226.

Shibayama, S. (2019). Sustainable development of science and scientists: Academic training in life science labs. Research Policy, 48, 676-692.

Shibayama, S., Baba, Y., \& Walsh, J. P. (2015). Organizational design of university laboratories: Task allocation and lab performance in Japanese bioscience laboratories. Research Policy, 44, 610-622.

Slaughter, S., Campbell, T., Holleman, M., \& Morgan, E. (2002). The " "traffic"” in graduate students: Graduate students as tokens of exchange between academe and industry. Science, Technology and Human Values, 27(2), 282-312. 
Spence, M. (1973). Job market signalling. The Quarterly Journal of Economics, 87(3), 355-374.

Stephan, P. E., Gurmu, S., Sumell, A. J., \& Black, G. (2007). Who's patenting in the university? Evidence from the survey of doctorate recipients. Economics of Innovation and New Technology, 16(2), 71-99.

Thune, T., \& Støren, L. A. (2015). Study and labour market effects of graduate students' interaction with work organisations during education. Education + Training, 57, 702-722.

Van Looy, B., Landoni, P., Callaert, J., van Pottelsberghe, B., Sapsalis, E., \& Debackere, K. (2011). Entrepreneurial effectiveness of European universities: An empirical assessment of antecedents and tradeoffs. Research Policy, 40, 553-564.

Van Looy, B., Ranga, L. M., Callaert, J., Debackere, K., \& Zimmerman, E. (2004). Combining entrepreneurial and scientific performance in academia: towards a compounded and reciprocal Matthew effect? Research Policy, 33, 425-441.

Walter, S. G., Parboteeah, K. P., \& Walter, A. (2013). University departments and self-employment intentions of business students: A cross-level analysis. Entrepreneurship Theory and Practice, 37, 175-200.

Wright, M., Vohora, A., \& Lockett, A. (2004). The formation of high-tech university spinouts: The role of joint ventures and venture capital investors. The Journal of Technology Transfer, 29, 287-310.

Zucker, L. G., Darby, M. R., \& Brewer, M. B. (1998). Intellectual human capital and the birth of U.S. biotechnology enterprises. American Economic Review, 88, 290-336.

Zucker, L. G., \& Darby, M. (1996). Star Scientists and institutional transformation: Patterns of invention and innovation in the formation of the biotechnology industry. Proceedings of the National Academy of Sciences USA, 93, 12709-12716.

Publisher's Note Springer Nature remains neutral with regard to jurisdictional claims in published maps and institutional affiliations. 